\title{
Increased Adenosine Triphosphatase in
}

\section{Leukocytes of Asthmatic Children}

\author{
Ronald G. Coffey, John W. Hadden, and Eluiott Middleton, Jr. \\ From the National Ásthma Center, Denver, Colorado 80204, and Memorial \\ Sloan-Kettering Cancer Center, New York 10021
}

A в S T R A C T Adenosine triphosphatase (ATPase) activities were compared in leukocytes of asthmatic and nonasthmatic children. Both $\mathrm{Mg}^{2+}$ - and $\mathrm{Ca}^{2+}$-dependent ATPase activities were significantly elevated in two membrane fractions ( 59 to $66 \%$ ) and in a supernatant fraction (68 to $72 \%$ ) prepared from sonicated leukocytes of asthmatic subjects. Intact cell surface or ecto ATPase was also elevated $(67$ to $76 \%$ ) in asthmatic leukocytes. Alternate day glucocorticosteroid therapy was associated with leukocyte ATPase activities intermediate between those for asthmatics not receiving steroids and for nonasthmatic control subjects. Incubation of normal leukocytes with $10^{-6} \mathrm{M}$ hydrocortisone or leukocyte membranes with $10^{-4}-10^{-3} \mathrm{M}$ hydrocortisone in vitro also resulted in decreased ATPase activities. The elevated leukocyte ATPase activities appear to relate to the adrenergic imbalance in asthma previously characterized by reduced beta adrenergic responsiveness of adenylate cyclase and suggest the possibility of more than one enzymatic abnormality intrinsic to the asthmatic condition.

\section{INTRODUCTION}

In experiments to further clarify the biochemical alteration present in patients with asthma, we and others (1-5) have found that the leukocytes of these patients provide a useful source of biological material to study and have provided data supporting the beta adrenergic blockade hypothesis of asthma elucidated by Szentivanyi (6) and reviewed recently by Middleton (7). Consistent with this hypothesis, the leukocytes of asthmatic chil-

A portion of this work was presented in abstract form in: Coffey, R. G., P. J. Logsdon, and E. Middleton, Jr.

1973. Leukocyte adenyl cyclase and ATPase in asthma: effect of corticosteroid therapy. Chest. 63: 2S.

Address reprint requests to Dr. Coffey at the Memorial Sloan-Kettering Cancer Center, New York 10021.

Received for publication 29 October 1973 and in revised form 18 March 1974. dren $(1,2)$ and adults (3-5) showed a diminished response of adenylate cyclase to catecholamine stimulation. Catecholamine stimulation of a number of tissues including leukocytes is associated with the potential for two pharmacologically distinct responses, the alpha and beta adrenergic. The beta adrenergic response has been linked to adenylate cyclase and the production of cyclic AMP. The alpha adrenergic response is often competitive, and it has been suggested that this results from a lowering of cyclic AMP (8). Recent studies of leukocytes of asthmatic subjects $(2,4)$ show that alpha adrenergic blockade with phentolamine restores normal beta adrenergic responsiveness of adenylate cyclase to catecholamine stimulation. In addition glucocorticosteroid treatment is associated with a partial restoration of normal beta adrenergic responsiveness in leukocytes of asthmatics $(1,9)$. Similarly glucocorticosteroids restore normal beta adrenergic responsiveness in human tracheal smooth muscle pharmacologically manipulated to simulate the asthmatic condition (10). These observations suggest that a competitive mechanism relating to enhanced alpha adrenergic sensitivity might be operant to produce apparent beta adrenergic blockade.

Belleau (11) proposed on theoretical ground that membrane adenosine triphosphatase (ATPase) would represent an ideal enzyme for alpha adrenergic modulation. We have offered support for this thesis by showing that in several cells divalent cation-dependent ATPase activities are stimulated by alpha adrenergic agonists and blocked by an alpha adrenergic blocker $(12,13)$. In applying this concept to asthma, a comparative study of two pairs of twins one of each pair with asthma and the other normal, showed that in addition to apparent beta adrenergic blockade the leukocytes of the asthmatic twins showed increased ATPase activity (14).

In the present study calcium- and magnesium-dependent ATPase activities were studied in the leukocytes of asthmatic children with and without steroid 
treatment and nonasthmatic controls in an effort to provide evidence for intrinsic alteration reflecting in vivo adrenergic imbalance.

\section{METHODS}

Subjects. Asthmatic children of both sexes were selected from the patient population at the National Asthma Center for these studies. They were subdivided into two groups depending on whether they were receiving steroids. Steroid therapy ranged from 5 to $50 \mathrm{mg}$ prednisone orally every other day with a mean dosage of $20 \mathrm{mg}$. Blood was drawn from these subjects $48 \mathrm{~h}$ after the last steroid administration. Most of these subjects as well as subjects not on steroid therapy also received combination drug therapy consisting of ephedrine, theophylline, and phenobarbital. All subjects were relatively free of symptoms on the morning of the study. The patients under study with very few exceptions showed airway hyperirritability (positive methacholine inhalation challenge), obstruction to air flow, and increased mid-expiratory time and hyperinflation. $\operatorname{IgE}$ levels ranged from a trace to $8,250 \mathrm{ng} / \mathrm{ml}$ and peripheral blood eosinophil counts ranged from 1 to $14 \%$. Approximately half of the patients showed positive skin test reactions to common allergens. Nonasthmatic boys and girls volunteered as control subjects. The numbers and ages of each group of subjects are provided in Table I.

Preparation of cells and membranes. $10 \mathrm{ml}$ of heparinized venous blood was obtained between 8 and 9 a.m. Leukocytes were prepared after sedimentation of red cells with dextran, as described previously (1). Pellets of leukocytes were washed with saline buffered with $1 \mathrm{mM}$ Tris $\cdot \mathrm{HCl}$ at $\mathrm{pH} 7.0$, centrifuged at room temperature, and resuspended in $4 \mathrm{ml}$ saline. These suspensions typically contained fewer than 1 platelet or red blood cell per leukocyte (1). Leukocyte distributions ranged from 20 to $40 \%$ lymphocytes and 50 to $70 \%$ neutrophils, with no significant differences between asthmatics and nonasthmatics. There were no significant differences in lymphocyte counts between the asthmatic subgroups, possibly because the lymphocyte counts return to normal $48 \mathrm{~h}$ after steroid administration (15). Eosinophil counts were routinely higher in asthmatics than nonasthmatics: the mean percent eosinophils was 6.1 for asthmatics not receiving steroids, 5.3 for asthmatics receiving steroids, and 2.9 for nonasthmatics.

A portion of each cell suspension was saved for measurement of intact cell surface or ecto ATPase activity. The remaining cells were sonicated at $0^{\circ} \mathrm{C}$ for $20 \mathrm{~s}$ with a Biosonic Sonifer (Bronwill Scientific, Rochester, N. Y.) at a power setting of 30 . Nuclei and large cell fragments $\left(P_{1}\right)$ were sedimented at $150 \mathrm{~g}$ for $10 \mathrm{~min}$ at $0^{\circ} \mathrm{C}$. A smaller membrane fraction $\left(\mathrm{P}_{2}\right)$ consisting of mitochondria, granules, endoplasmic reticulum, and plasma membrane was collected by centrifugation of the $\mathrm{P}_{1}$ supernatant at $44,000 \mathrm{~g}$ for $30 \mathrm{~min}$ at $0^{\circ} \mathrm{C}$. Centrifugation of the resulting supernatant at $140,000 \mathrm{~g}$ for $60 \mathrm{~min}$ yielded no visible precipitate and was, therefore, not performed routinely.

ATPase. Membrane fractions $\mathrm{P}_{1}$ or $\mathrm{P}_{2}$ were suspended in $3 \mathrm{ml}$ of $50 \mathrm{mM}$ Tris $\cdot \mathrm{HCl}, \mathrm{pH} 7.5$, by using a Dounce homogenizer; $0.4 \mathrm{ml}$ of suspensions of membranes, intact cells, or supernatant was mixed with $0.05 \mathrm{ml}$ of $50 \mathrm{mM}$ $\mathrm{MgCl}_{2}$ or $\mathrm{CaCl}_{2}$ (dissolved in $50 \mathrm{mM}$ Tris, $\mathrm{pH} \mathrm{7.5)}$ ) and incubated at $37^{\circ} \mathrm{C}$. The reaction was initiated by adding 0.05 $\mathrm{ml}$ of $20 \mathrm{mM}$ ATP (sodium salt, Sigma Chemical Co., St. Louis, Mo., dissolved in $50 \mathrm{mM}$ Tris and adjusted to $\mathrm{pH}$ 7.5) and continued with gentle shaking for $30 \mathrm{~min}$. The
TABLE I

Subjects used in ATPase studies

\begin{tabular}{lrrr}
\hline & & \multicolumn{2}{c}{ Age } \\
\cline { 3 - 4 } & & Range & Mean \\
\hline Asthmatics not receiving steroids & & \\
$\quad$ Number of males: & 18 & $11.5-15.6$ & 13.4 \\
Number of females: & 6 & $12.5-14.4$ & 13.9 \\
Total: & 24 & $11.5-15.6$ & 13.6 \\
& & & \\
Steroid-treated asthmatics & & \\
Number of males: & 13 & $9.8-16.0$ & 13.0 \\
Number of females: & 4 & $12.6-14.4$ & 13.6 \\
Total: & 17 & $9.8-16.0$ & 13.2 \\
& & & \\
Nonasthmatics & 12 & $9.9-16.0$ & 12.4 \\
$\quad$ Number of males: & 12 & $11.0-15.0$ & 12.6 \\
Number of females: & 8 & $9.9-16.0$ & 12.5 \\
Total: & 20 & & \\
\hline
\end{tabular}

reaction was terminated with $0.05 \mathrm{ml}$ of $4 \mathrm{~N} \mathrm{HClO}_{4}$ and protein was removed by centrifugation. The supernatant was neutralized with $0.05 \mathrm{ml}$ of $4 \mathrm{~N} \mathrm{KOH}$, and the $\mathrm{KClO}_{4}$ precipitate was removed by centrifugation. Adenosine diphosphate (ADP) or inorganic phosphate was determined in the supernatant by methods described (16), and protein was assayed according to the method of Lowry, Rosebrough, Farr, and Randall (17).

\section{RESULTS}

Optimum reaction conditions. Optimum conditions for measuring leukocyte ATPase were established with normal adult cells. The conversion of ATP to ADP and phosphate by sonicated leukocytes in the presence of $\mathrm{Mg}^{2+}$ was found to be linear with time up to $30 \mathrm{~min}$ (Fig. 1). Between 30 and $60 \mathrm{~min}$ the reaction rates decreased slightly. The net formation of phosphate was $95 \%$ of the formation of ADP at $30 \mathrm{~min}$. The discrepancy may be due to minimal utilization of ATP by other phosphorylation reactions occurring in the whole sonicates. The close agreement between net formation of ADP and phosphate indicates that assay of either product would represent a fairly accurate measurement of ATPase activity in this system.

The conversion of ATP to ADP by $\mathrm{Mg}^{2+}$ - and $\mathrm{Ca}^{2+}-$ dependent enzymes associated with membranes was proportional to the amount of enzyme added as seen in Fig. 2. Broad $\mathrm{pH}$ optima were found between 7.2 and 8.0 for both $\mathrm{Mg}^{2+}$ - and $\mathrm{Ca}^{2+}$-dependent ATPase in both $P_{1}$ and $P_{2}$ fractions of leukocytes (Fig. 3). In addition a small peak of $\mathrm{Ca}^{2+}$-dependent ATPase at $\mathrm{pH} 5.2$ was observed for leukocyte $\mathrm{P}_{1}$ and $\mathrm{P}_{2}$ fractions representing 50 and $24 \%$, respectively, of the activities measured at $\mathrm{pH}$ 7.5. No additional peaks of $\mathrm{Mg}^{2+}$-dependent activity were noted, suggesting that there were no significant 


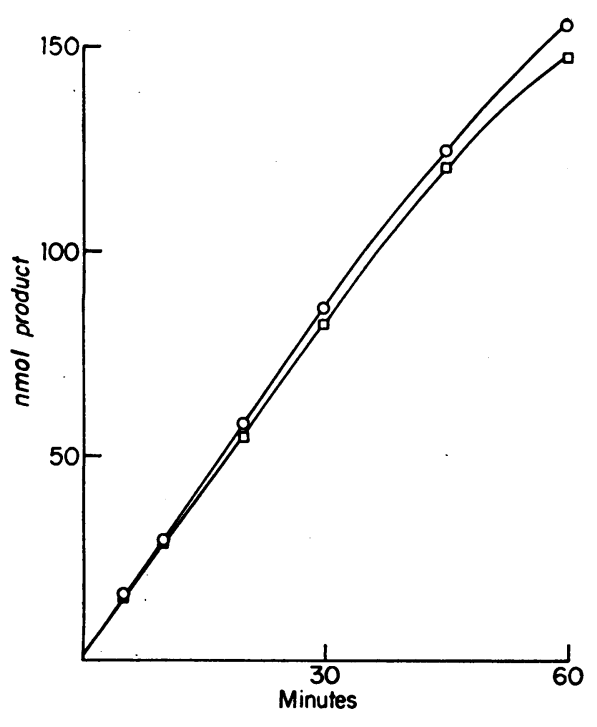

FIGURE 1 Leukocyte $\mathrm{Mg}^{2+}$-ATPase as a function of time. Sonicated, unfractionated, nonasthmatic leukocytes were incubated with $2 \mathrm{mM}$ ATP and $5 \mathrm{mM} \mathrm{MgCl}_{2}$ for varying times as described in Methods. ADP (O-O) and phosphate $(\square-\square)$ were measured after incubation. Each point represents the mean of three determinations.

contributions to breakdown of ATP by nonspecific phosphatases in these membrane preparations.

Optimum levels of $\mathrm{Mg}^{2+}$ and $\mathrm{Ca}^{2+}$ were found to be $5 \mathrm{mM}$ for ATPase in both membrane fractions of leukocytes (data not shown) when $2 \mathrm{mM}$ ATP was used. The following reaction conditions, similar to those

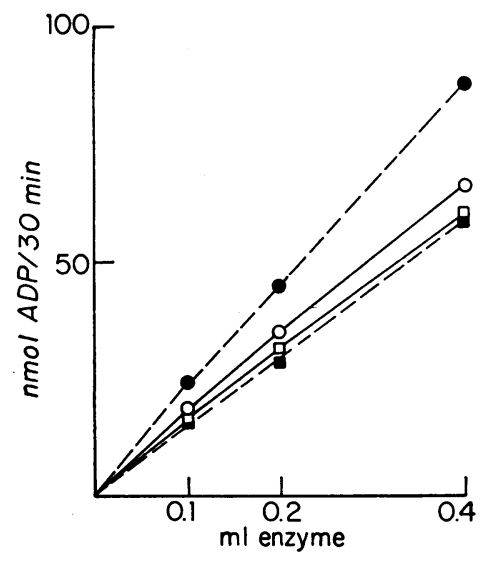

Figure 2 Leukocyte membrane ATPase as a function of enzyme. Membrane fractions prepared from nonasthmatic leukocytes were incubated with $2 \mathrm{mM}$ ATP and $5 \mathrm{mM}$ divalent cation for $30 \mathrm{~min}$ and the product ADP determined as described in Methods. Activities are plotted for varying amounts of $\mathrm{Mg}^{2+}$-ATPase in fraction $\mathrm{P}_{1}(\mathrm{O}-\mathrm{O})$, $\mathrm{Ca}^{2+}$-ATPase in fraction $\mathrm{P}_{1}(\square-\square), \mathrm{Mg}^{2+}$-ATPase in fraction $\mathrm{P}_{2}(---\bullet)$, and $\mathrm{Ca}^{2+}$-ATPase in fraction $\mathrm{P}_{2}$ ( $\square-(-)$ in a total volume of $0.5 \mathrm{ml}$. Each point represents the mean of three determinations.

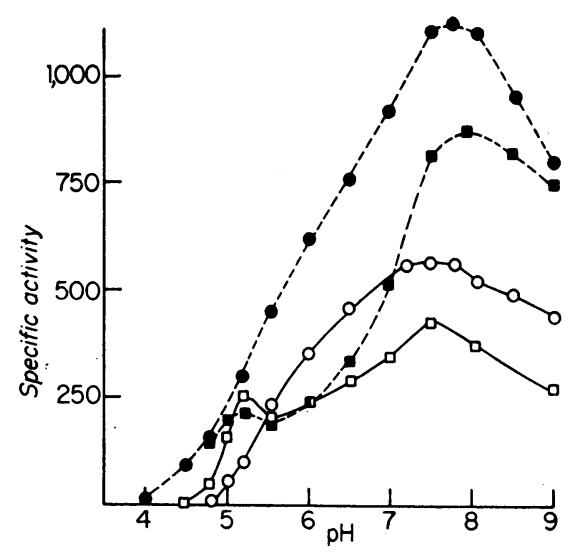

FIgURE 3 Leukocyte membrane ATPase as a function of $\mathrm{pH}$. The experiment was conducted as described for Fig. 2 with $50 \mathrm{mM}$ Tris. $\mathrm{HCl}$ buffered at various $\mathrm{pH}$ values. The $\mathrm{pH}$ was measured in duplicate tubes at $37^{\circ} \mathrm{C}$ after the 30 -min incubation. Each point represents the mean of three determinations.

used previously for lymphocyte ATPase (16) and for leukocyte ATPase (18), were, therefore, routinely used: $5 \mathrm{mM}$ divalent cation, $2 \mathrm{mM}$ ATP, $50 \mathrm{mM}$ Tris at $\mathrm{pH}$ 7.5, and 20-100 $\mathrm{gg}$ leukocyte protein in a final volume of $0.5 \mathrm{ml}$, incubated at $37^{\circ} \mathrm{C}$ for $30 \mathrm{~min}$. ADP was routinely measured and specific activity expressed as nmol ADP formed in $30 \mathrm{~min}$ per milligram protein.

Comparison of ATPase activity in leukocytes of asthmatic and nonasthmatic subjects. Specific activities of $\mathrm{Mg}^{2+}$ - and $\mathrm{Ca}^{2+}$-dependent ATPase in fractions $\mathrm{P}_{1}$ and $\mathrm{P}_{2}$ of leukocytes from asthmatic children not on steroid therapy, asthmatics receiving steroid therapy, and nonasthmatic children are compared in Fig. 4. For

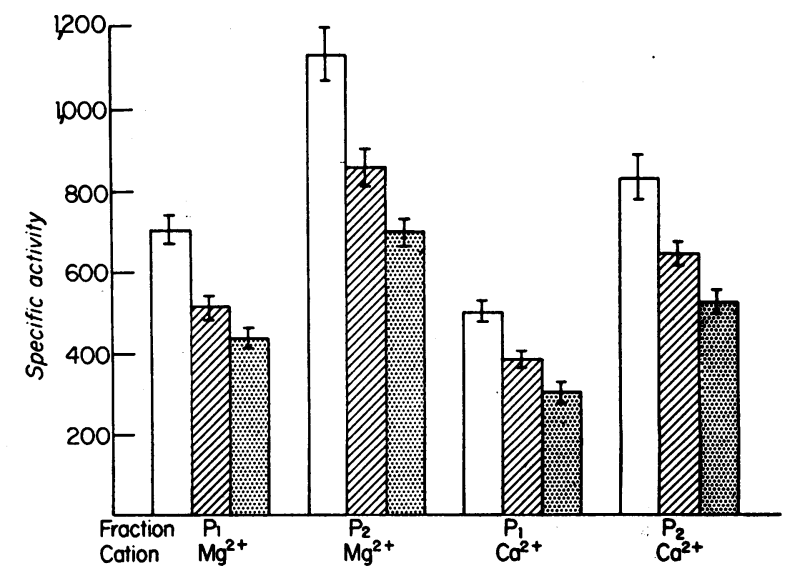

Figure 4 Membrane ATPase activities. The mean ATPase specific activities ( $\mathrm{nmol} \mathrm{ADP} / 30 \mathrm{~min} / \mathrm{mg}$ protein) are plotted for membrane fractions $P_{1}$ and $P_{2}$ of leukocytes from 24 asthmatic children not receiving steroids (clear bars), 17 asthmatic children receiving steroid therapy (hatched bars), and 20 nonasthmatic children (dotted bars). Error bars indicate SEM. 
each group of subjects the mean of the $\mathrm{Mg}^{2+}$-ATPase was greater than the $\mathrm{Ca}^{2+}$-ATPase, and the specific activities in fraction $P_{2}$ were greater than those in $P_{1}$. Specific activities of the ecto ATPase and supernatant fraction ATPase are compared for the three groups in Fig. 5. The specific activity of the $\mathrm{Mg}^{2+}$-dependent component of ecto ATPase was greater than the $\mathrm{Ca}^{2+}$ dependent component while the reverse was true for the supernatant activities.

For each enzyme measured, the activity was greatest for asthmatics not receiving steroid therapy, intermediate for asthmatics receiving steroids, and lowest for the nonasthmatic subjects. Considerable variation in all activities was observed within any group of subjects, while variations less than $20 \%$ were recorded in repeated experiments with the same individual. Data for all cell fractions is summarized in Table II as ratios of specific activity for the three groups of subjects. The ratio of activities for asthmatics to nonasthmatics ranged from 1.59 to 1.76 , and the ratio for asthmatics to steroid-treated asthmatics ranged from 1.30 to 1.49 . Differences between the steroid-treated group and the nonasthmatics were smaller and were not significant for ecto and supernatant ATPase activities.

To test the effects of drugs commonly used for the treatment of asthma on ATPase activities, three nonasthmatic adult males volunteered to take tablets containing ephedrine, theophylline, and phenobarbital for several days. No significant changes in any of the ATPase activities were noted after this regimen, which ranged from 5 days for two subjects to 8 days for the third subject (Table III).

In further attempts to explain the different ATPase activities among the three groups of subjects we compared the distribution of protein and total enzyme activity among the cell fractions (Table IV). A range

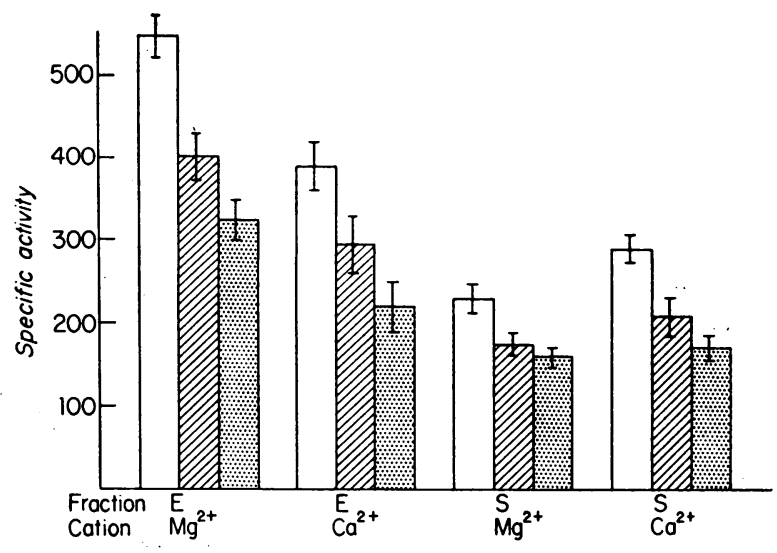

FIgURE 5 Supernatant and ecto ATPase activities. The mean ATPase specific activities ( $\mathrm{nmol}$ ADP/30 min/mg protein) are plotted for ecto (E) and supernatant (S) fractions of leukocytes from 24 asthmatic children not receiving steroids (clear bars), 17 asthmatic children receiving steroid therapy (hatched bars), and 20 nonasthmatic children (dotted bars). Error bars indicate SEM.

of $30-38 \%$ of total leukocyte protein was found in the $\mathrm{P}_{1}$ fraction, $21-25 \%$ in the $\mathrm{P}_{2}$ fraction, and $40-45 \%$ in the supernatant. These values were variable, possibly due to minor differences in the extent of cell disruption, but no significant differences were found among the means for the groups of subjects. Also, no significant differences were noted between males and females within any group of subjects when comparing protein distribution or ATPase activities.

Effects of hydrocortisone in vitro. Two types of experiments were performed in an effort to duplicate in vitro the effect of corticosteroid therapy on leukocyte ATPase activity. First (Table V), hydrocortisone was added directly to membranes of leukocytes and incubated for $10 \mathrm{~min}$ at $37^{\circ} \mathrm{C}$ before addition of ATP. The

TABLE II

Ratios of ATPase Specific Activity

\begin{tabular}{cccccccc}
\hline $\begin{array}{c}\text { Cell } \\
\text { fraction }\end{array}$ & Cation & A/N & $P$ & A/A + S & $P$ & A + S/N & $P$ \\
\hline $\mathrm{P}_{1}$ & $\mathrm{Mg}$ & 1.62 & $<0.01$ & 1.37 & $<0.01$ & 1.18 & $\mathrm{NS}$ \\
$\mathrm{P}_{1}$ & $\mathrm{Ca}$ & 1.66 & $<0.01$ & 1.31 & $<0.01$ & 1.27 & $<0.02$ \\
$\mathrm{P}_{2}$ & $\mathrm{Mg}$ & 1.62 & $<0.01$ & 1.32 & $<0.01$ & 1.23 & $<0.02$ \\
$\mathrm{P}_{2}$ & $\mathrm{Ca}$ & 1.59 & $<0.01$ & 1.30 & $<0.01$ & 1.22 & $<0.02$ \\
$\mathrm{E}$ & $\mathrm{Mg}$ & 1.67 & $<0.01$ & 1.35 & $<0.01$ & 1.24 & $\mathrm{NS}$ \\
$\mathrm{E}$ & $\mathrm{Ca}$ & 1.76 & $<0.01$ & 1.31 & $<0.05$ & 1.35 & $\mathrm{NS}$ \\
$\mathrm{S}$ & $\mathrm{Mg}$ & 1.68 & $<0.01$ & 1.34 & $<0.05$ & 1.26 & $\mathrm{NS}$ \\
$\mathrm{S}$ & $\mathrm{Ca}$ & 1.72 & $<0.01$ & 1.49 & $<0.01$ & 1.23 & $\mathrm{NS}$ \\
\hline
\end{tabular}

Ratios of ATPase specific activity ( $\mathrm{nmol} \mathrm{ADP}$ per $\mathrm{mg}$ protein per $30 \mathrm{~min}$ ) are indicated for the groups of subjects: A, asthmatics not receiving steroids $(n=24)$; A $+\mathrm{S}$, asthmatics receiving steroid therapy $(n=17)$; and N, normal children $(n=20)$. $P$ values were calculated from the individual specific activity data by Student's $t$ test; NS indicates no significant difference ( $P$ not less than 0.05 ). 
TABLE III

Effect of Bronchodilator Drugs on Leukocyte ATPase

\begin{tabular}{|c|c|c|c|c|c|c|}
\hline \multirow[b]{2}{*}{ Subject } & \multirow[b]{2}{*}{ (days) } & \multirow[b]{2}{*}{ Fraction } & \multicolumn{2}{|c|}{$\mathrm{Mg}^{2+-A T P a s e}$} & \multicolumn{2}{|c|}{$\mathrm{Ca}^{2+}-\mathrm{ATPase}$} \\
\hline & & & Before & After & Before & After \\
\hline K. M. & (5) & $\begin{array}{l}P_{1} \\
P_{2} \\
E \\
S\end{array}$ & $\begin{array}{l}328 \pm 11 \\
529 \pm 23 \\
246 \pm 10 \\
103 \pm 4\end{array}$ & $\begin{array}{l}333 \pm 15 \\
553 \pm 31 \\
255 \pm 13 \\
107 \pm 7\end{array}$ & $\begin{array}{l}219 \pm 14 \\
381 \pm 28 \\
159 \pm 12 \\
123 \pm 11\end{array}$ & $\begin{array}{l}234 \pm 7 \\
421 \pm 19 \\
172 \pm 5 \\
133 \pm 9\end{array}$ \\
\hline R. G. & (6) & $\begin{array}{l}P_{1} \\
P_{2} \\
E \\
S\end{array}$ & $\begin{array}{l}550 \pm 8 \\
889 \pm 16 \\
389 \pm 15 \\
170 \pm 13\end{array}$ & $\begin{array}{l}503 \pm 11 \\
727 \pm 23 \\
343 \pm 12 \\
148 \pm 6\end{array}$ & $\begin{array}{l}350 \pm 9 \\
665 \pm 7 \\
254 \pm 6 \\
210 \pm 11\end{array}$ & $\begin{array}{l}342 \pm 5 \\
636 \pm 9 \\
246 \pm 12 \\
215 \pm 4\end{array}$ \\
\hline D. C. & (8) & $\begin{array}{l}P_{1} \\
P_{2} \\
E \\
S\end{array}$ & $\begin{array}{l}417 \pm 18 \\
680 \pm 31 \\
320 \pm 15 \\
129 \pm 7\end{array}$ & $\begin{array}{l}395 \pm 19 \\
649 \pm 25 \\
302 \pm 16 \\
125 \pm 9\end{array}$ & $\begin{array}{l}275 \pm 14 \\
473 \pm 38 \\
191 \pm 12 \\
149 \pm 8\end{array}$ & $\begin{array}{l}286 \pm 5 \\
501 \pm 3 \\
200 \pm 9 \\
143 \pm 6\end{array}$ \\
\hline
\end{tabular}

Leukocyte ATPase activities were determined by ADP assay in triplicate as described in Methods for three nonasthmatic adult males before and after taking bronchodilator medication (Verequad, Knoll Pharmaceutical Company, Orange, N. J., consisting of ephedrine, theophylline, and phenobarbital) four times a day for the indicated number of days. Specific activities ( $\mathrm{nmol}$ ADP per $30 \mathrm{~min}$ per $\mathrm{mg}$ protein) $\pm \mathrm{SD}$ are given for leukocyte enzyme preparations $P_{1}, P_{2}, E$ (ecto), and $S$ (supernatant) before and after taking medication. No significant differences occurred in any of the activities due to the drugs.

$\mathrm{Mg}^{2+}$-ATPase activity was reduced in a dose-dependent manner in three experiments by hydrocortisone ranging from $10^{-6}$ to $10^{-3} \mathrm{M}$. To achieve the highest hydrocortisone concentrations, hydrocortisone sodium succinate was used because of its greater water solubility.

TABLE IV

Total Protein and ATPase Units in Leukocytes

\begin{tabular}{lllll}
\hline & Fraction: & $P_{1}$ & $P_{2}$ & $S$ \\
\hline & \multicolumn{4}{c}{ Protein : percent found in } \\
& subcellular fractions \\
Asthmatics not on steroids & 38 & 22 & 40 \\
Asthmatics receiving steroids & 35 & 21 & 44 \\
Nonasthmatics & 30 & 25 & 45
\end{tabular}

$$
\mathrm{Mg}^{2+} \text {-ATPase }
$$

Asthmatics not on steroids Asthmatics receiving steroids Nonasthmatics

$$
\mathrm{Ca}^{2+} \text {-ATPase }
$$

Asthmatics not on steroids Asthmatics receiving steroids

ATPase : total units per $100 \mathrm{mg}$ leukocyte protein*

Nonasthmatics

$\begin{array}{rrr}2,700 & 2,500 & 920 \\ 1,800 & 1,810 & 750 \\ 1,310 & 1,750 & 612 \\ & & \\ 1,910 & 1,840 & 1,160 \\ 1,340 & 1,350 & 915 \\ 910 & 1,320 & 760\end{array}$

* Approximately $70 \mu \mathrm{g}$ protein per million leukocytes were measured in HC10, precipitates by the technique of Lowry et al. (17).
In controls with $5 \times 10^{-8} \mathrm{M}$ sodium succinate, the ATPase activity was not affected, indicating that inhibition by hydrocortisone sodium succinate was due to the steroid.

Second (Table VI), intact leukocytes were preincubated with $10^{-6} \mathrm{M}$ hydrocortisone at $37^{\circ} \mathrm{C}$ for varying times before the preparation of membranes. In the first experiment progressive inhibition was observed for preincubation times ranging from 5 to $120 \mathrm{~min}$. In the second experiment puromycin was added to the cells in one set of tubes during a 60 -min preincubation with $10^{-8} \mathrm{M}$ hydrocortisone. The puromycin caused a $16 \%$ decrease in $\mathrm{Mg}^{2+}$-ATPase specific activity measured subsequently in the membranes, but did not alter the percent decrease due to hydrocortisone. This suggests that inhibition by hydrocortisone is not mediated by effects on protein synthesis.

\section{DISCUSSION}

The beta adrenergic blockade hypothesis of asthma advanced by Szentivanyi (6) has prompted a search for abnormalities of function and sensitivity in the adenylate cyclase-cyclic AMP system of various cells and tissues of patients with asthma. A number of studies with isolated leukocytes by ourselves $(1,2,14)$, Parker and coworkers $(3,9,19)$, Alston, Patel, and Kerr (4) and Gillespie, Valentine, and Lichtenstein (5) have provided evidence indicating that in asthma this system 
manifests a reduced sensitivity to beta adrenergic stimulation:

(a) Basal activity of adenylate cyclase is depressed $(2,3,5,9,19)$.

(b) Beta adrenergic stimulation of adenylate cyclase is depressed (1-5); however, prostaglandin $E_{1}$ stimulation is normal (19).

(c) Corticosteroid treatment of patients in vivo and of cells in vitro restores basal levels of adenylate cyclase (9), and restores normal beta adrenergic sensitivity $(1,9)$.

(d) Alpha adrenergic blockade in vitro restores normal beta adrenergic sensitivity of adenylate cyclase $(2,4)$.

The accumulated evidence, while not explaining why, indicates that this system is suppressed and most specifically to beta adrenergic stimulation. The restoration of normal responsiveness with steroids and with alpha adrenergic blockade indicates that the reduced responsiveness might result from enhanced alpha adrenergic sensitivity or reduced steroid sensitivity.

These possibilities provided the rationale for examining other enzyme systems for abnormality of function and sensitivity. In many cells there appears to be a reciprocal relationship between alpha and beta adrenergic responses $(7,20,21)$ and between ATPase and adenylate cyclase activities $(22,23)$. This may be due in part to competition by the two enzymes for substrate $(8,16)$ and in part to direct inhibition of ATPase by cyclic AMP $(23,24)$. Our experiments indicated that membrane ATPase activity of leukocytes and other hematopoietic cells can be stimulated by catecholamines through an alpha adrenergic mechanism (12, 13). Others have reported stimulation by catecholamines of $\mathrm{Mg}^{2+}$-ATPase in brain (25) and erythrocytes (26), and of $\mathrm{Na}^{+}, \mathrm{K}^{+}, \mathrm{Mg}^{2+}$-ATPase of brain (27) and liver (24).

TABLE V

Hydrocortisone Inhibition of $\mathrm{Mg}^{2+}-A$ TPase

\begin{tabular}{cccc}
\hline & Hydrocortisone & \multicolumn{2}{c}{ Hydrocortisone Na succinate } \\
\hline & $10^{-6} M$ & $10^{-4} M$ & $10^{-3} M$ \\
Exp. 1 & 98 & 93 & $81^{*}$ \\
Exp. 2 & $85^{*}$ & $74^{*}$ & $50^{*}$ \\
Exp. 3 & 94 & $80^{*}$ & $68^{*}$ \\
\hline
\end{tabular}

Data is given as percent of control $\mathrm{Mg}^{2+}$-ATPase activity measured in nonasthmatic leukocyte membranes $\left(\mathrm{P}_{1}+\mathrm{P}_{2}\right)$ in replicates of six as described in Methods. Standard deviations (not shown) were less than $5 \%$ in all cases. Hydrocortisone or hydrocortisone sodium succinate (Sigma Chemical Co., St. Louis, Mo.) was added in $0.1 \mathrm{ml}$ aliquots of Tris buffer, $\mathrm{pH} 7.5$, at 5 times the indicated final concentration and incubated with membranes at $37^{\circ} \mathrm{C}$ for $10 \mathrm{~min}$ before adding ATP.

* Significant inhibition occurred.
TABLE VI

Preincubation of Leukocytes with Hydrocortisone

\begin{tabular}{rccc}
\hline & $\begin{array}{c}\text { Preincubation } \\
\text { minutes }\end{array}$ & $\begin{array}{c}\text { Control } \\
\text { activity }\end{array}$ & $\begin{array}{c}\text { Percent of } \\
\text { control }\end{array}$ \\
\hline Exp. 1 & 5 & 552 & 80 \\
1 & 45 & 552 & 65 \\
1 & 120 & 552 & 51 \\
Exp. 2 & 60 & 423 & 87 \\
$2^{*}$ & 60 & 397 & 85 \\
\hline
\end{tabular}

Leukocytes from nonasthmatic subjects were preincubated at $37^{\circ} \mathrm{C}$ in Hank's balanced salt solution for the indicated time with or without $10^{-6} \mathrm{M}$ hydrocortisone (Sigma Chemical Co., St. Louis, Mo.) in replicates of six. Cells were then washed twice with saline and sonicated. $\mathrm{Mg}^{2+}$-ATPase of membranes $\left(\mathrm{P}_{1}+\mathrm{P}_{2}\right)$ was determined in triplicate for each preincubation tube. Control activity is expressed as nmol ADP per mg protein per $30 \mathrm{~min}$. Inhibition by preincubation with hydrocortisone was significant $(P<0.01)$ in every case.

* Puromycin was present at $100 \mu \mathrm{g} / \mathrm{ml}$ in the preincubation mixture.

These observations supporting the theory (11) of alpha adrenergic modulation of ATPase prompted us to examine the leukocytes of asthmatics and controls for altered basal levels of ATPase activity which might reflect in vivo adrenergic imbalance. Intact cells were examined for ecto ATPase activity. The membrane ATPase activities of disrupted cells were separated by rate-zonal centrifugation to yield crude fractions representing nuclei and large fragments of plasma membrane $\left(\mathrm{P}_{1}\right)$ and smaller fragments of membranes corresponding to plasma, mitochondrial, and ribosomal constituents $\left(\mathrm{P}_{2}\right)$. These fractions represent the major subcellular components containing ATPase activities (over $80 \%$ of the total) and were assayed in the presence of magnesium or calcium ions to optimize those conditions under which alpha adrenergic stimulation had been previously observed $(12,13)$. These fractions while admittedly crude correspond to the magnesium- and calcium-dependent ATPase activities associated by others with cellular functions of magnesium (28) and calcium $(29,30)$ transport, passive permeability (31), nutrient transport $(16,32,33)$, and locomotive (34) and secretory functions (35).

In each of the experimental conditions the leukocytes of asthmatic patients showed greater ATPase activity than those of age-sex matched subjects without asthma. In addition, asthmatic patients treated with corticosteroids showed an intermediate ATPase activity consistent with their clinical improvement on the steroid therapy. This increased ATPase activity manifest in the leukocytes of asthmatics could not be attributed to treatment with other bronchodilator therapy since these

Increased Leukocyte ATPase in Asthma 
medications showed no effect on the leukocyte ATPase activity of normal subjects so treated. Similarly, no real differences in component cell populations studied existed to explain the differences in ATPase activity observed. The increased leukocyte ATPase activity would appear then to be intrinsic to the asthmatic state.

Corticosteroid treatment of both the patient and the isolated leukocytes was associated with a reduction of the increase in basal ATPase activity of the cells. The effect of hydrocortisone at physiologic concentrations to reduce ATPase activity in a puromycin-resistant manner, in conjunction with its direct effect at somewhat higher concentrations to reduce ATPase activity in isolated membrane fractions, offers evidence for a direct membrane action of hydrocortisone independent of the more generally accepted action to modify nuclear metabolism and protein synthesis (36). This effect of corticosteroids to decrease ATPase activity has been observed with in vivo treatment followed by isolation of various tissues (37-39) and with in vitro treatment of a cultured cell line (40). The biochemical basis of this action remains to be clarified.

The interpretation of the present findings in relation to previous conceptions concerning beta adrenergic blockade, although tentative at this time, raises important questions concerning the relationship of the adenylate cyclase-cyclic AMP system to other hormone responsive enzyme systems involved in cellular regulatory function. Based upon experiments indicating that beta adrenergic stimulation is associated with depressed allergic mediator release from mast cells and leukocytes $(41,42)$ and with bronchodilitation (6), it may be concluded that the asthmatic patient being defective in response to this stimulation is prone to enhanced immunologically induced mediator release and subsequent bronchoconstriction. Both alpha adrenergic and cholinergic mechanisms have recently been implicated in both enhanced allergic mediator release (43) and in bronchoconstrictive mechanisms $(7,44)$. Insofar as these mechanisms appear to be enhanced in their activity in asthma, it seems reasonable to speculate that the enzyme systems mediating these influences will be found to be increased in their activity. The alpha adrenergic-ATPase relationship is suggested by the present studies. Similarly, cholinergic-cyclic GMP relationships have been observed in a number of tissues (45) including lymphocytes (45-47) and lung (45), and the cyclic GMP second messenger system has been proposed as an opposing influence to the cyclic AMP system $(45,48)$. The suggestion that cyclic GMP may be increased in the tissues of asthmatics, thus facilitating bronchoconstriction and mediator release, was made by Polson, Krzanowski, and Szentivanyi (49), who have shown that manipulations producing an asthma- like condition in rodents are associated with an increase in the levels of cyclic GMP in their lungs. We predict, then, that the beta adrenergic defect observed in the cells of asthmatics may well result from more primary imbalances in the membrane ATPase and guanylate cyclase-cyclic GMP systems.

The therapeutic approach to patients with asthma has been to stimulate their adenylate cyclase-cyclic AMP system through the combined use of beta adrenergic agonists (isoproterenol and epinephrine), cyclic AMP phosphodiesterase inhibitors (theophylline and caffeine), and glucocorticosteroids. This approach is pharmacologically sound and is usually associated with symptomatic improvement. The present findings concerning ATPase suggest that the adrenergic imbalance present in asthma is associated with increased activity of other enzyme systems and raises the possibility that were these systems to be better understood, a more primary defect might emerge, which would allow the development of a more effective patient therapy.

\section{ACKNOWLEDGMENTS}

The technical assistance of Patricia J. Logsdon in performing some ATPase determinations is gratefully acknowledged. The cooperation of all children who participated in the experiments in greatly appreciated.

This work was supported by U. S. Public Health Service Grants AI 09619 and AI 10400 (Allergic Diseases Center Grant).

\section{REFERENCES}

1. Logsdon, P. J., E. Middleton, Jr., and R. G. Coffey. 1972. Stimulation of leukocyte adenyl cyclase by hydrocortisone and isoproterenol in asthmatic and nonasthmatic subjects. J. Allergy Clin. Immunol. 50: 45-56.

2. Logsdon, P. J., D. V. Carnright, E. Middleton, Jr., and R. G. Coffey. 1973. The effect of phentolamine on adenylate cyclase and on isoproterenol stimulation in leukocytes from asthmatic and nonasthmatic subjects. $J$. Allergy Clin. Immunol. 52: 148-157.

3. Parker, C. W., and J. W. Smith. 1973. Alterations in cyclic adenosine monophosphate metabolism in human bronchial asthma. I. Leukocyte responsiveness to $\beta$ adrenergic agents. J. Clin. Invest. 52: 48-59.

4. Alston, W. C., K. R. Patel, and J. W. Kerr. 1974. Response of leukocyte adenyl cyclase to isoprenaline and effect of alpha-blocking drugs in extrinsic bronchial asthma. Br. Med. J. 1: 90-93.

5. Gillespie, E., M. Valentine, and L. M. Lichtenstein. 1974. Cyclic AMP metabolism in asthma: studies with leukocytes and lymphocytes. J. Allergy Clin. Immunol. $53: 27-33$

6. Szentivany, A. 1968. The beta adrenergic theory of the atopic abnormality in bronchial asthma. J. Allergy. 42: 203-232.

7. Middleton, E., Jr. 1972. Autonomic imbalance in asthma with special reference to beta adrenergic blockade. Adv. Inter. Med. 18 : 177-197.

8. Robison, G. A., R. W. Butcher, and E. W. Sutherland. 1971. Cyclic AMP. Academic Press, Inc., New York. 223-228. 
9. Parker, C. W., M. G. Huber, and M. L. Baumann. 1973. Alterations in cyclic AMP metabolism in human bronchial asthma. III. Leukocyte and lymphocyte responses to steroids. J. Clin. Invest. 52: 1342-1348.

10. Townley, R. G., T. Honrath, and H. M. Guirgis. 1972. The inhibitory effect of hydrocortisone on the alpha adrenergic responses of human and guinea pig isolated respiratory smooth muscle. J. Allergy Clin. Immunol. 49: 88. (Abstr.).

11. Belleau, B. 1967. Stereochemistry of adrenergic receptors: newer concepts of the molecular mechanism of action of catecholamines and antiadrenergic drugs at the receptor level. Ann. N. Y. Acad. Sci. 139: 580-605.

12. Coffey, R. G., J. W. Hadden, E. M. Hadden, and E. Middleton, Jr. 1971. Stimulation of ATPase by norepinephrine: an alpha-adrenergic receptor mechanism. Fed. Proc. 30: 497. (Abstr.).

13. Coffey, R. G., and E. Middleton, Jr. 1973. Release of histamine from rat mast cells by lysosomal cationic proteins. Possible involvement of adenylate cyclase and adenosine triphosphatase in pharmacologic regulation. Int. Arch. Allergy Appl. Immunol. 45: 593-611.

14. Falliers, C. J., R. R. de A. Cardoso, H. N. Bane, R. Coffey, and E. Middleton, Jr. 1971. Discordant allergic manifestations in monozygotic twins: Genetic identity vs. clinical, physiologic, and biochemical differences. $J$. Allergy. 47 : 207-219.

15. Chai, H., and A. Gilbert. 1973. The effect of alternateday prednisone on the white blood count in children with chronic asthma. J. Allergy Clin. Immunol. 51: 6570.

16. Hadden, J. W., E. M. Hadden, E. E. Wilson, R. A. Good, and R. G. Coffey. 1972. Direct action of insulin on plasma membrance ATPase activity in human lymphocytes. Nat. New Biol. 235 : 174-176.

17. Lowry, O. H., N. J. Rosebrough, A. L. Farr, and R. J. Randall. 1951. Protein measurement with the Folin phenol reagent. J. Biol. Chem. 193: 265-275.

18. Block, J. B., and S. L. Bonting. 1964. Sodium-potassium activated adenosinetriphosphatase and cation transport in normal and leukemic human leukocytes. Enzymol. Biol. Clin. 4 : 183-198.

19. Parker, C. W., M. L. Baumann, and M. G. Huber. 1973. Alterations in cyclic AMP metabolism in human bronchial asthma. II. Leukocyte and lymphocyte responses to prostaglandins. J. Clin. Invest. 52: 13361341.

20. Watlington, C. O. 1969. $\alpha$-Adrenergic inhibition of sodium ion transport: the interaction of vasopressin and 3',5'-AMP. Biochim. Biophys. Acta. 193: 394-402.

21. Turtle, J. R., and D. M. Kipnis. 1967. An adrenergic receptor mechanism for the control of cyclic $3^{\prime}, 5^{\prime}$-adenosine monophosphate synthesis in tissues. Biochem. Biophys. Res. Commun. 28: 797-802.

22. Mosinger, B., and M. Vaughan. 1969. Adenosine $3^{\prime}, 5^{\prime}-$ monophosphate and regulation of lipolysis in rat adipose tissue. Adv. Exp. Med. Biol. 3: 63-74.

23. Mózsik, G. Y. 1970. Direct inhibitory effect of adenosine monophosphates on $\mathrm{Na}^{+}-\mathrm{K}^{+}$-dependent ATPase prepared from human gastric mucosa. Eur. J. Pharmacol. 9: 207210.

24. Luly, P., O. Barnabei, and E. Tria. 1972. Hormonal control in vitro of plasma membrane bound $\left(\mathrm{Na}^{+}-\mathrm{K}^{+}\right)$ATPase of rat liver. Biochim. Biophys. Acta. 282: 447452.
25. Kaack, B. 1972. Influence of acetylcholine and adrenaline on ATPase activity. Comp. Gen. Pharmacol. 3: 296-298.

26. Mirčevová, L., and A. Šimonová. 1969. Effect of adrenaline, noradrenaline, and insulin on $\mathrm{Mg}^{++}$-dependent ATPase. Experientia (Basel). 25: 1028-1029.

27. Yoshimura, K. 1973. Activation of Na-K activated ATPase in rat brain by catecholamine. J. Biochem. 74: 389-391.

28. Beauchamp, R. S., S. Silver, and J. D. Hopkins. 1971. Uptake of $\mathrm{Mg}^{2+}$ by $\mathrm{KB}$ cells. Biochim. Biophys. Acta. 225 : 71-76.

29. Whittam, R., and K. P. Wheeler. 1970. Transport across cell membranes. Annu. Rev. Physiol. 32: 21-60.

30. Schatzman, H. J., and G. L. Rossi. 1971. The $\left(\mathrm{Ca}^{2+}+\right.$ $\mathrm{Mg}^{2+}$ )-activated membrane ATPase in human red cells and their possible relations to cation transport. Biochim. Biophys. Acta. 241 : 379-392

31. Bowler, K., and C. J. Duncan. 1967. Evidence implicating a membrane ATPase in the control of passive permeability of excitable cells. J. Cell Physiol. 70: 121-126.

32. Hadden, J. W., E. M. Hadden, and R. G. Coffey. 1971 Lymphocyte responses to hormones: stimulation of glucose uptake and membrane ATPase by insulin and norepinephrine. Fed. Proc. 30: 687. (Abstr.)

33. Hadden, J. W., E. M. Hadden, and R. A. Good. 1971. Alpha adrenergic stimulation of glucose uptake in human erythrocyte, lymphocyte, and lymphoblast. Exp. Cell Res. 68: 217-219.

34. Huxley, H. E. 1973. Muscular contraction and cell motility. Nature (Lond.). 243: 445-449.

35. Stormorken, H. 1969. The platelet release reaction. Its General aspects and relation to phagocytosis/pinocytosis. Sand. J. Clin. Lab. Invest. Suppl. 107: 115.

36. O'Malley, B. W. 1971. Mechanisms of action of steroid hormones. N. Engl. J. Med. 284: 370-377.

37. Takagi, I., and K. Yamamoto. 1969. Effects of thyroidectomy, adrenalectomy, thyroid hormones, and glucocorticoids on $\mathrm{Na}^{+}, \mathrm{K}^{+}$-activated ATPase of rat anterior pituitary. Jap. J. Physiol. 19: 465.

38. Ribo, J. M., and F. Ponz. 1969. Magnesium-activated ATPase in the sodium- and potassium-dependent enzyme system from rat small intestine. Rev. Esp. Fisiol. 25 : $257-266$.

39. Hellerström, C., I. Täljedal, and B. Hellman. 1965 Quantitative studies on isolated pancreatic islets of mammals. 5' Nucleotidase and adenosine triphosphatase activities in normal and cortisone-treated rats. Endocrinology. 76: 315-322.

40. Melnykovych, G., M. A. Swayze, C. F. Bishop, and C. Costlow. 1969. Effects of prednisolone on esterases in heteroploid cells of human origin. Biochim. Biophys. Acta. 184: 672-674.

41. Orange, R. P., M. A. Kaliner, P. J. LaRaia, and K. F. Austen. 1971. Immunological release of histamine and slow reacting substance of anaphylaxis from human lung. II. Influence of cellular levels of cyclic AMP. Fed. Proc. 30: 1725-1729.

42. Lichtenstein, L. M., and R. DeBernardo. 1971. Immediate allergic response: in vitro action of cyclic AMPactive and other drugs on the two stages of histamine release. J. Immunol. 107: 1131-1136.

43. Kaliner, M., R. P. Orange, and K. F. Austen. 1972. Immunological release of histamine and slow reacting substance of anaphylaxis from human lung. IV. En-

Increased Leukocyte ATPase in Asthma 
hancement by cholinergic and $\alpha$-adrenergic stimulation. J. Exp. Med. 136 : 556-567.

44. Reed, C. E. 1974. Abnormal autonomic mechanisms in asthma. J. Allergy Clin. Immunol. 53 : 34-41.

45. Goldberg, N. D., M. K. Haddox, D. K. Hartle, and J. W. Hadden. 1973. The biological role of cyclic 3',5'guanosine monophosphate. In Pharmacology and the Future of Man. Proceedings of the 5th International Congress of Pharmacology. Karger, Basel. 5: 146.

46. Hadden J. W., E. M. Hadden, and N. D. Goldberg. Cyclic GMP and Cyclic AMP in lymphocyte metabolism and proliferation. In Cyclic AMP, Immune Response and Tumor Growth. W. Braun, L. M. Lichtenstein, and C. W. Parker, editors. Springer Verlag Inc., New York. In press.

47. Strom, T. B., C. B. Carpenter, M. R. Garovoy, K. F.
Austen, J. P. Merrill, and M. Kaliner. 1973. The modulating influence of cyclic nucleotides upon lymphocytemediated cytotoxicity. J. Exp. Med. 138: 381-393.

48. Goldberg, N. D., M. K. Haddox, E. Dunham, C. Lopez, and J. W. Hadden. 1974. The Yin Yang hypothesis of biological control: opposing influences of cyclic GMP and cyclic AMP in the regulation of cell proliferation and other biological processes. In Cold Spring Harbor Conferences on Cell Proliferation. Vol. 1. Control of Proliferation in Animal Cells. B. Clarkson and R. Baserga, editors. 609-626.

49. Polson, J. B., J. J. Krzanowski, and A. Szentivanyi. 1974. The effect of histamine $(H)$ on the pulmonary levels of cyclic nucleotides in normal mice and under conditions of pharmacological or bacterial sensitization. J. Allergy Clin. Immunol. 53: 100. (Abstr.). 